\title{
Mobilizing Altruistic Civic Actions Through School Science
}

\author{
Going Up Against The Borg ${ }^{\text {TM }}$
}

\section{J. LAWRENCE BENCZE*}

*OISE, University of Toronto; larry.bencze@utoronto.ca

\begin{abstract}
Responses
JASTE is a non-refereed, open-access, journal. We encourage reader feedback on contributions to it. Please send your comments, suggestions, etc. about this paper to the author of this paper, Larry Bencze. Thanks!
\end{abstract}

\begin{abstract}
Whether or not people in advantages contexts around the globe recognize it, it seems clear that our world is in serious peril. While small fractions of populations enjoy safety, basic comforts and many luxuries, increasingly more people are suffering from job insecurities, a range of health problems and manipulation facilitated by mass surveillance systems. Meanwhile, as few benefit, most of us are threatened by devastating climate change, environmental spoilage and species losses — all apparently undermined by systematic democratic assaults. Although network conceptions of phenomena may suggest distribution of responsibilities for such ills, much data and argument place considerable blame on few rich pro-capitalist individuals (e.g., financiers) and groups (e.g., corporations, think tanks and transnational trade organizations). Given collusion of governments in such social and ecological injustices, it appears extremely necessary that power in masses of people be rallied to critically interrogate actions of powerful entities and develop and take social actions that may lead to increases in social justice and environmental wellbeing. An important context, in light of roles of fields of science and technology in enactment of power, for promotion of such critical and action-oriented civic engagement is school science. Such roles have, indeed, been acknowledged — at least in part — for about the last half-century through 'science-in-context' educational domains like 'STSE' (Science, Technology, Society, Environment) education. Such more contextualized approaches have, however, been marginalized in most contexts. They are either given little attention or treated in somewhat 'token' ways (given severity of harms) by emphasizing individual — albeit reasoned - choices, which happen to be a priority of many capitalists. Marginalization of potential critical and action-oriented science education seems to have, meanwhile, dramatically increased with recent advent of 'STEM' (Science, Technology, Engineering and Mathematics) education initiatives - many of which prioritize teaching and learning of 'products,' such as laws, theories and innovations, of STEM fields and skills to develop them, at expense of educating students about problematic STSE relationships and preparation for possibly-rectifying actions. Given its hegemonic influences, as discussed here, one approach to promoting ecojustice through science education may be through encouraging and enabling youth to develop commodities that are both functional and aim to maximize wellbeing for individuals, societies and environments (WISE). Studies of one teacher's efforts in this regard suggest considerable successes with such WISE engineering - although, as reported here, successes seem to come at expense of some educational losses that have been tied to pro-capitalist science education. Although such tempered achievements may seem frustrating, those promoting social justice and environmental wellbeing through school science may be motivated by emergent successes and possibilities for mobilizing them across networks of living, nonliving and symbolic entities.
\end{abstract}




\section{Global Draconian Hegemony}

As Greta Thunberg, a teenaged activist from Sweden, said to delegates at the annual gathering of world financial and political elite in Davos, Switzerland, in January 2019, "Our house is on fire!" Climate change is escalating at such a pace, in other words, that she said we need to treat it — not as a 'risk,' as she said many politicians were doing, but - like an emergency that is equivalent to imminent destruction of our home. In making such a dramatic statement, Ms. Thunberg could be echoing advice from Noam Chomsky (2017), noted linguist, philosopher, cognitive scientist, historian, political activist, and social critic, who said that as recently stressed by the Bulletin of the Atomic Scientists (Mecklin, 2019) - humanity is facing at least two existential threats; that is, devastation from nuclear war and from climate change (the latter largely attributed to human fossil fuel combustion) (Steffen et al., 2018). They added that a 'crisis of democracy' was undermining efforts to overcome these threats. At the same, among numerous other harms, it is apparent that humans continue to be plagued by ongoing illnesses associated with manufactured foods (Weber, 2009), pharmaceuticals (Norman et al., 2011) and tobacco (Verma, 2009); and, industrial activities are severely compromising many eco-spaces (Leonard, 2010) - contributing to what many suggest is our current $\left(6^{\text {th }}\right.$, anthropogenic) mass extinction (Moore, 2016).

On the one hand, it may seem appropriate to focus blame for harms like those above on fields of science and technology and related fields, like mathematics and engineering. Based on material-semiotic ontological conceptions (e.g., Fenwick \& Edwards, 2012), on the other hand, fields of science and technology (and many related entities) are linked into vast networks of reciprocal relations and, accordingly, responsibility for various ills may best be considered distributed across such systems of actants. The extent to which intentions, knowledge, etc. are equally-distributed across material-semiotic networks has, however, been questioned. Foucault (2008), for instance, suggests that some actants are able to 'orchestrate' many others in ways that align with powerful actants' purposes — referring to such cooperating sets of actants as dispositifs. Among entities that could rally numerous actants to their causes, many scholars and others suggest few or none rival influences - especially in at least the last five decades — of pro-capitalist individuals (e.g., financiers) and groups (e.g., corporations) (e.g., Hardt \& Negri, 2009; McMurtry, 2013; Pierce, 2013). After a period of social security and infrastructure spending and labour protections that followed devastation from the Great Depression and World War II, neoliberal forms of capitalism developed; that is, in contrast to earlier, more

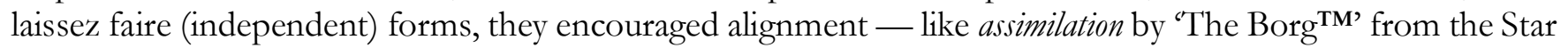
Trek $^{\mathrm{TM}}$ entertainment series — of myriad living, nonliving and symbolic entities (including those associated with governments) to work for capitalist aims (Harvey, 2005; Springer, Birch \& McLeavy, 2016). A key feature of neoliberalism for about the last three decades has been globalization; that is, infiltration of capitalist perspectives and practices throughout the world and, especially, facilitation of such hegemony through work of transnational entities like the World Trade Organization, International Monetary Fund, World Bank, Organisation for Economic Cooperation and Development and associated think tanks like the Atlas Foundation (Ball, 2012). This complex and extremely powerful transnational programme appears to have served interests of capitalists quite well. Piketty (2014), for instance, suggests that capitalism has been intensely concentrating wealth throughout the neoliberal period and, moreover, seems destined to continue to do so at unprecedented rates - largely at expense of many other humans and living things and nonliving environments. Oxfam (2019), an international aid agency, suggests that wealth has now concentrated to the point that 26 billionaires have about the same total wealth as the poorest $50 \%$ of the world's population $(\sim 3.8$ billion people).

\footnotetext{
${ }^{1}$ https://www.theguardian.com/environment/2019/jan/25/our-house-is-on-fire-greta-thunberg16-urges-leaders-to-act-onclimate
}

Journal for Activist Science \& Technology Education, Volume 10, Issue 1 (2019) [jps.library.utoronto.ca/index.php/jaste] 
Although globalizing neoliberalism has been extremely 'successful,' especially in terms of wealth concentration by capitalists, intense nationalist movements have become increasingly prominent in the last few years in several nations - including in Austria, Brazil, Hungary, India, Poland, Turkey and the USA. To a great extent, these appear to have been promoted by so-called right-wing populists (RWP); that is, leaders who blame 'elites' for many personal and social struggles experienced by large fractions of populations and promise — often in salvationary tones — better futures for masses of 'common' people (Laclau, 2005). While it may be somewhat early to judge such nascent movements, numerous analysts suggest that many RWP leaders' promises — often associated with unpredictable and seemingly erratic behaviour (Kirkpatrick, 2017) — seem to be serving as 'smoke screens' to distract citizens from awareness of further, often much more intense, implementation of pro-capitalist policies, such as tax reductions for the rich, de-regulation of large businesses and privatization and/or elimination of former public services (Rushe et al., 2017), apparently stronglyencouraged by so-called 'dark money' (e.g., financiers and corporations) (Mayer, 2016). In the sense that RWP populists appear to 'capitalize' on crises generated, in part, by neoliberalism, they seem to declare a 'state of exception' (Agamben, 2005), enabling them to justify implementation of extreme capitalist policies - a process called disaster capitalism (Klein, 2007).

\section{Rectifying Roles for School Science}

Because governments - along with, to a great extent, transnational nongovernmental organizations — often facilitate contexts that appear to have contributed to private sector gains, largely at expense of wellbeing of most other living and nonliving things, it seems clear that increases in public consciousness and civic activism that prioritize social justice and environmental wellbeing are required. If such transformations in civic engagement are to occur, it is apparent that science and technology education must play prominent roles. Key agents in capitalists' gains have been their twin influences over fields of science and technology in ways that favour private profit over general wellbeing (e.g., Klein, 2014; Krimsky, 2003; Mirowski, 2011; Moore, 2015) and over their educational counterparts to generate workers (at various skill levels) to develop and manage means of production and masses of compliant workers and enthusiastic and unquestioning consumers (Bencze \& Alsop, 2014; Giroux \& Giroux, 2006; Hodson, 2011; Roth \& Désautels, 2002; Santos, 2009).

For about the last half century, governments in several countries have included in science curricula teaching/learning goals — known as 'STSE' (science, technology, society, environment) education — that acknowledge that fields of science do not work in isolation but, rather, are intertwined in relationships with fields of technology/engineering and with myriad other members of societies and with living and nonliving environments (Pedretti \& Nazir, 2011). Similar such 'science-in-context' programmes around the world include socioscientific issues (SSI) education (Zeidler, 2014) and education around socially-acute questions (SAQs) (Legardez \& Simonneaux, 2006).

Many 'science-in-context' educational movements like those above may encourage and enable learners to develop and engage in social actions to address controversies and/or potential harms to living and nonliving things linked to fields of science and technology. However, many of them tend to be limited to facilitating students' logically-reasoned decision-making leading to personal positions on a range of controversies (Hodson, 2011; Levinson, 2013; Sjöström et al., 2017). Also, while such 'science-in-context' educational formations have existed for decades, school science systems have tended to marginalize them; focusing, instead, on teaching/learning of 'achievements' — such as laws, theories and inventions/innovations - of fields of science and technology, often at expense of consideration of larger social and environmental entanglements of such fields. A governing ideology seems to be that school science is mainly about what is (e.g., our current conceptions of phenomena), rather than also about what ought to be (e.g., changes in government regulations that may improve products of science and technology) (Levinson, 2018). Indeed, this 
tendency appears to be intensifying. In about the last decade, possibilities for education that acknowledges sometimes problematic relationships among fields of science and technology and societies and environments and prepares students to engage in well-planned social actions to address perceived harms like those noted above appear to be under increasingly extreme threats - largely due to rapid incorporation over that period of 'STEM' (science, technology, engineering \& mathematics) education initiatives. Although such initiatives vary considerably, it seems that they tend to focus on teaching/learning of widely-accepted laws, theories and inventions/innovations of science and technology and techniques/methods for generating and disseminating them - largely, apparently, aiming to identify and educate relatively few professionals and technical workers in STEM fields who may assist businesses to successfully compete in a 'neo-Sputnik' era where, for example, companies based mostly in North America compete against those in Asia and the European Union (Pierce, 2013). As reflected in plans for the latest national science curriculum in the USA, such orientations for STEM education aim to further augment hierarchical societal systems:

The primary driver of the future economy and concomitant creation of jobs will be innovation, largely derived from advances in science and engineering. . . 4 4 percent of the nation's workforce is composed of scientists and engineers; this group disproportionately creates jobs for the other 96 percent (NRC, 2011, p. 2).

At the same time, it is apparent that many STEM education initiatives — while claiming inclusivity (e.g., more females and people of different ethnicities in STEM fields) and connectedness (e.g., among the four disciplines) - tend to exclude references to claims from fields of humanities and social sciences that may allude to problematic aspects of STEM fields (Hoeg \& Bencze, 2017a,b; Gough, 2015; Zeidler, 2016), such as aforementioned compromises associated with business arrangements with fields of science and technology. In doing so, designers of STEM education initiatives tend to present reductionist conceptions of the four fields, focusing mainly on techniques and their widely-accepted products, in a process that Callon (1991) referred to as punctualization; that is, making a complex system appear much simpler than it likely is in reality. Missing elements in such reductive processes in STEM education tend to be those that would make the four fields seem problematic and, in turn, cast negative lights on their financial backers, thus causing disenchantment among workers and consumers (Bencze et al., 2018; Pierce, 2013).

In light of the above discussion, it seems clear that educational programmes are needed that would enlighten students about sometimes problematic relationships among fields of science and technology and powerful societal actants and, where they perceive harms, help them to develop expertise, confidence and motivation to develop and implement personal and social actions that may effectively address them.

\section{Towards Altruistic Civic Engagement Through School Science}

Since 2006, I have been working with graduate students, teachers and others to use action research to learn about educators' efforts to encourage and enable learners to develop and implement personal and social actions that they believe may address personal, social and/or environmental harms associated with science and technology that concern them. This action research programme has been based on the 'STEPWISE' (Science \& Technology Education Promoting Wellbeing for Individuals, Societies \& Environment) schema for arranging lessons and student activities (Bencze, 2017a). Development of this schema was inspired by writing of Derek Hodson (2003, 2011), especially, about needs for promotion of civic actions through science education and was constructed to address teaching/learning goals in curricula for the province of Ontario, Canada, which prioritized achievement in three broad domains; that is, i) 'products' (e.g., laws, theories \& innovations) of science and technology; ii) skills for science inquiry and technology design and communications; and, iii) relationships among fields of science and technology and societies and environments (STSE). The original ver sion of the framework (upper right, Figure 1) organized these domains (with STSE split into 'education' and 'actions' and skills split into 'education' and 'research') into a tetrahedron to signify that students could, 
'altruistically' (acknowledging possibilities for personal fulfilment through acts for others), use some of their literacy in the four peripheral domains to try to improve — through "STSE Actions" — wellbeing of (other) individuals, societies and/or environments ('WISE'). This goal is meant to contrast sharply with perspectives and practices that perceive science education as a 'selection and training camp' for few potential knowledge producers (e.g., scientists \& engineers) who may, as suggested above, help govern jobs (and, likely, habits of personal consumption, etc.) of most citizens in a world prioritizing individual competitiveness and consumerism (Bencze, 2001; Giroux \& Giroux, 2006).

In our initial efforts to encourage science educators to base lessons and student activities on the tetrahedral version of STEPWISE (upper right, Figure 1), it readily became apparent that teachers found the schema quite impractical - in that, for example, it implies that teachers must engage learners in all five domains simultaneously. Consequently, I developed a more sequential schema - the latest version of which is shown at the bottom of Figure 1 - that teachers found more useful. This schema suggests that teachers provide students with 'apprenticeship' lessons and student activities that may eventually enable and motivate them to self-direct researchinformed and negotiated action projects ('Students' Self-led RiNA Projects") to address harms in STSE relationships. Depending on various factors, such as students' ages, abilities and stages of learning, 'apprenticeships' may consist of one or more 3-phase constructivism-informed cycles; that is:

1. Students Reflect: The

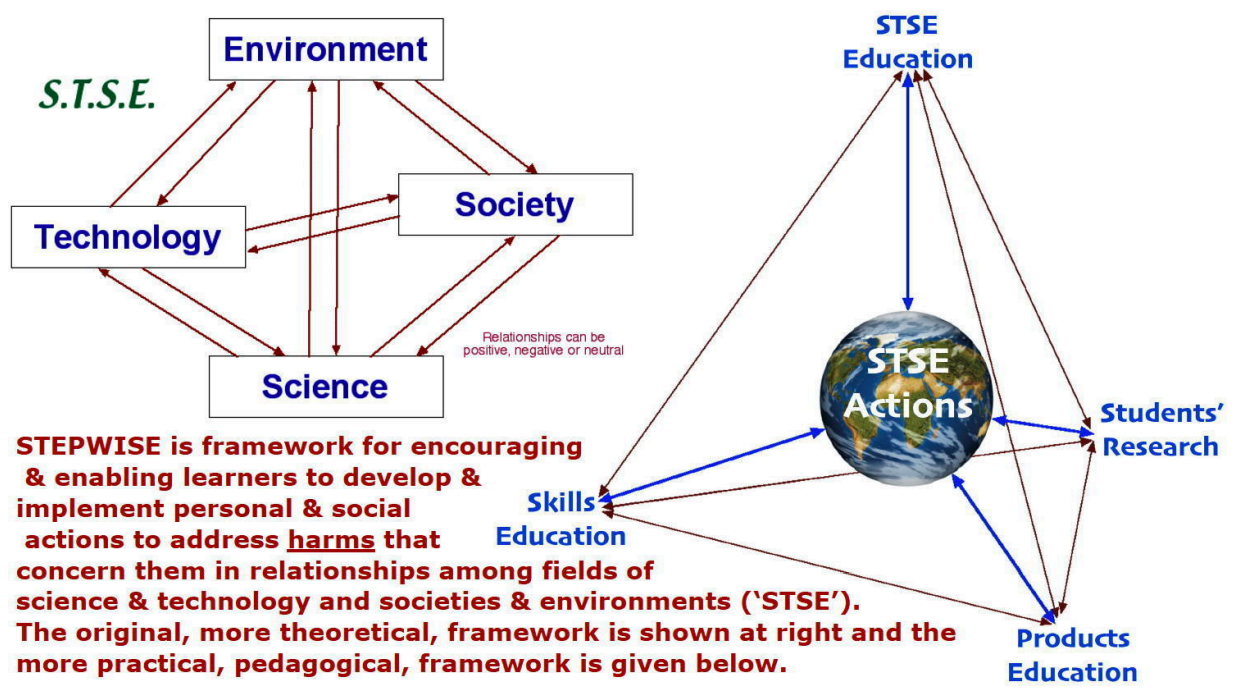
more practical, pedagogical, framework is given below.

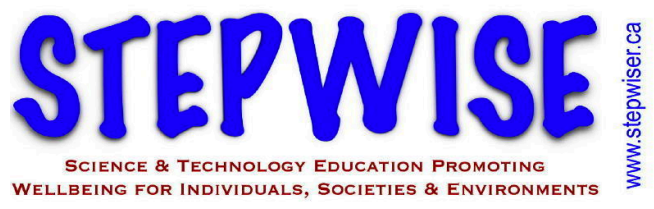
WELLBEING FOR INDIVIDUALS, SOCIETIES \& ENVIRONMENTS
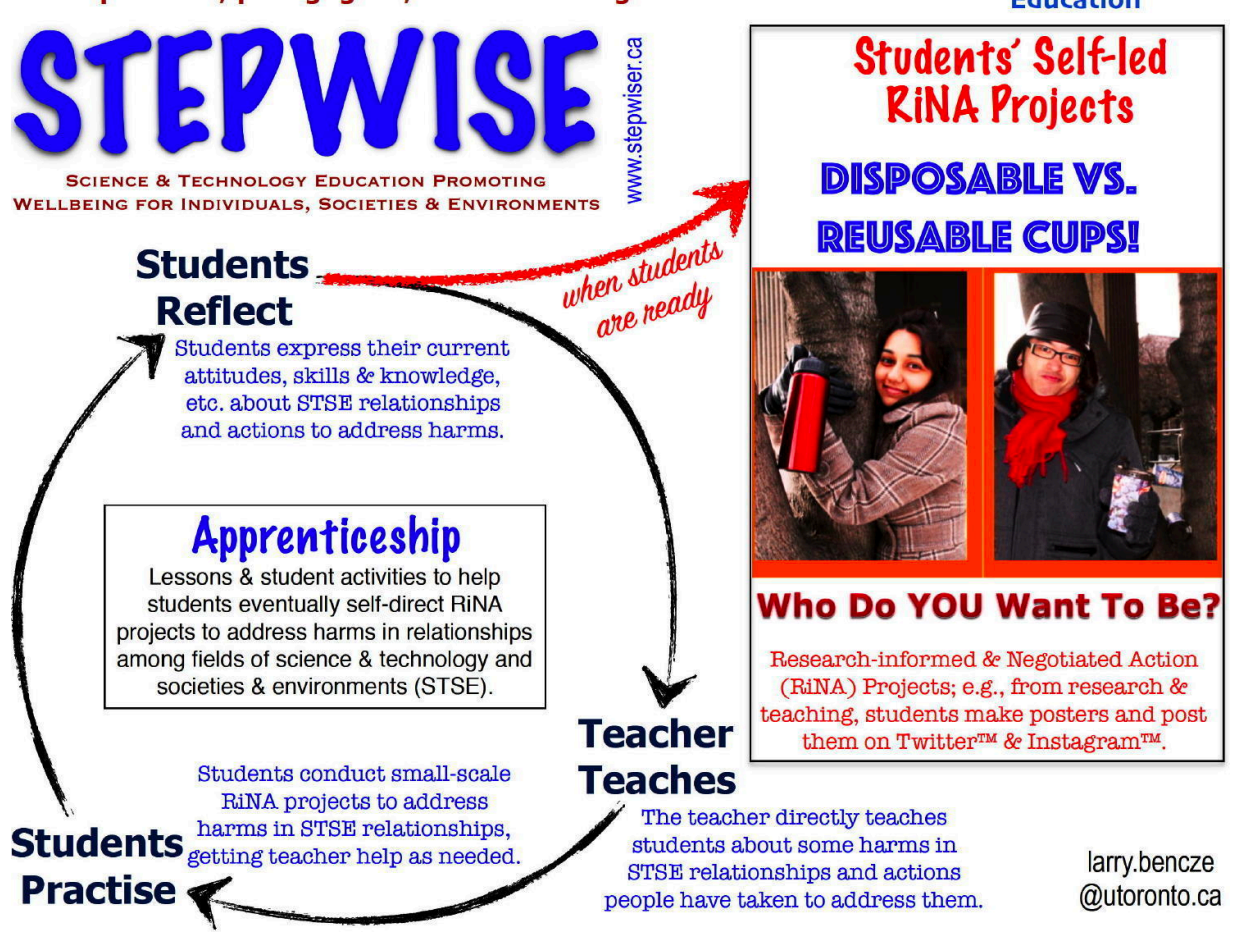

\section{Figure I: STEPWISE Schema.}

teacher often provides students with 'stimuli' (e.g., commodities, like cell phones, generated with help from science and technology) that may encourage students to 'express' (e.g., via discussions, drawings, models) their pre-instructional attitudes, skills and knowledge ('ASK'), etc. regarding STSE relationships (including actions people might take to address harms in them); 
2. Teacher Teaches: The teacher directly teaches difficult-to-discover important ASK (e.g., about roles of transnational corporations) in STSE relationships and examples of RiNA projects conducted by others to address harms in them. Such ASK may be difficult to discover because, for example, of some students' limited cultural and social capital and because of manipulation of information of relevant publicly-available information (e.g., via the Internet). Shortly after being taught important ASK, students are then asked to evaluate and deepen their understanding of them through some application activities, such as answering questions regarding documentaries of RiNA projects to address STSE issues;

3. Students Practise: To deepen and more personalize students' expertise, confidence and motivation for them, the teacher encourages students to develop and implement small-scale RiNA projects to address harms in STSE relationships identified by students. Projects are mostly student-led, but the teacher may assist some students, in different ways, depending on students' needs and requests.

Our research over about a decade with science educators in formal primary, secondary and tertiary (teacher education) education contexts and in after-school clubs indicate that the schema at the bottom of Figure 1 has helped many students to develop significant expertise, confidence and motivation for selfdirecting (mostly) varied and personally-meaningful RiNA projects - several examples of which can be found in Bencze and Alsop (2014) and Bencze (2017a) and in two special issues of the open-source, non-refereed, journal, JASTE, at: goo.gl/N00b3s; and, bit.ly/2JGIgtf.

Although there appears to be much to celebrate about successes of the STEPWISE pedagogical schema (lower section, Figure 1) for encouraging and enabling learners to develop and implement RiNA projects to address harms of their concern in STSE relationships, it also seems clear that such approaches are generally not well-supported and, indeed, occur in relatively rare contexts. It was apparent, for instance, from our 3year study of facilitated action research about one teacher's efforts to promote self-led RiNA projects that 'successes' in that regard benefitted from relatively rare existence of a supportive dispositif, including alignment, in that case, among such entities as: official curriculum goals, school administrative and collegial supports, teacher beliefs in possible adverse influences of powerful people and groups on science and engineering (and related entities), sufficient material resources (Bencze \& Krstovic, 2017). In this light, those wanting to promote more critical analyses of STSE relationships and civic actions to address related harms, educators, administrators, teachers, and many others need to engage in multiple actions to help form a dispositif that may challenge pro-capitalist dispositifs and work towards increased social justice and environmental wellbeing.

\section{Developing and Mobilizing 'WISE' Commodities}

In the more than dozen years of working with the STEPWISE framework (lower half, Figure 1) in action research modes (Noffke \& Somekh, 2009) with teachers of science (mainly), most of them have tended to encourage - or, been able to encourage — students to engage in educational forms of action to address harms (or controversies) that students perceive in STSE relationships. A good example of such an action was the educational video (goo.gl/jeAihg) that a tenth-grade student produced as a result of her research (and previous education, experiences, etc.) into the nature of cosmetics (especially 'foundation' make-up). That student's RiNA project — and others like it — can be understood with reference to the schematic in Figure 2. Adapted from a similar schema published by Roth (2001) to depict reciprocal relationships between phenomena of the 'World' and representations ('Signs') of them that he suggested were involved in such translations that are common to 'science' (i.e., World $\rightarrow$ Sign) and 'technology' (Sign $\rightarrow$ World), this version of the schema can represent STEM fields (with engineering in the same direction as technology and with mathematics involved in both directions) and it can represent RiNA projects - with 'research' comparable to 'science' and 'actions' comparable to 'technology'/'engineering,' and with negotiations throughout. Regarding the example provided 

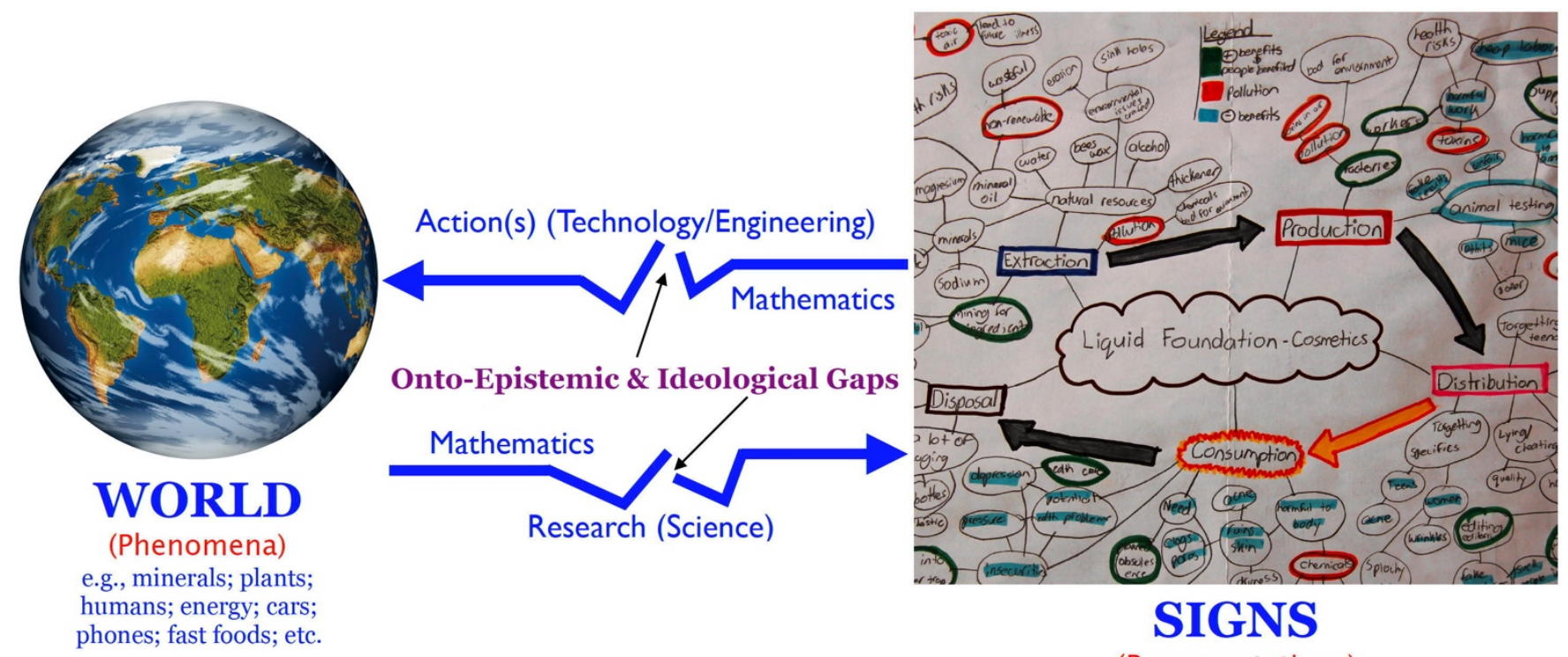

SIGNS

(Representations)

e.g., pictures; drawings; blueprints; equations; models, posters; etc.

\section{Figure 2: RiNA Projects Schematic.}

in Figure 2, the student had conducted secondary research (mostly via the Internet) to learn more about cosmetics and, then, a short survey (primary research) to learn more about peers' uses, knowledge and understanding of cosmetics and, then, used available knowledge, skills and attitudes to develop the educational video - which, at the time of writing here, has been viewed over 700 times. A key feature of her work appeared to relate to the students' 'narrowing' of ideological gaps between representations of cosmetics, which tend to be relatively punctualized and de-problematized, as she provided much more contextual (depunctualized) and problematizing information to her viewers than often is the case with companies (Baudrillard, 1998; Usher, 2010). (While ideological gaps between World and Sign involve intentionality, ontological (composition of entities) and epistemological (characteristics of procedures) gaps are less so.)

With educational actions, such as the video discussed above, translations from Sign $\rightarrow$ World are only partial or speculative; that is, they may be recommendations for a different World (e.g., less cosmetic use), but they may or may not be realized - largely depending on ideological positions of those engaged (e.g., consumers) in the translations. Students (and others) may, however, choose to make more complete translations from Sign $\rightarrow$ World. This was, indeed, our aim in an action research project we called, WISE TechDesign - in which we worked to encourage and enable secondary school students to develop technology/engineering designs, as actions, that not only performed a desired function but, also, tried to maximize wellbeing of individuals, societies and environments (WISE) (Bencze \& Krstovic, 2017). Focusing on engineering/technology design may be a prudent tack, given apparent hegemonic influences of STEM education initiatives. In terms of actor-network ontological conceptions (Latour, 2005), such a tack may help insert an alternative actant into an existing network and - through processes of translation (reciprocal movement of 'inscriptions' [e.g., conceptions of thought \& action (Latour \& Woolgar, 1986)] among actants - mobilize conceptions (e.g., critiques of STSE relationships and rectifying social actions) throughout the network. Promotion of engineering/technology design appears to be a prominent feature of many STEM education initiatives, often stated in terms of needs to create innovative products and services that may solve various social and environmental problems. Pleasant and Olson (2018), for instance, suggest that STEM educators "... engage learners in building a wind or water turbine connected to a generator to light a bulb. An associated driving question or driving problem might be: How can I illuminate a light bulb using water or wind power?" (p. 46). Although there have, clearly, been numerous engineering designs that have helped many 
people — such as with hip replacement surgery (Weinstein, 2007) - and have addressed many environmental problems (e.g., to clean up oil spills [Fingas, 2015]), there also are critiques suggesting that many such 'technofixes' (Huesemann \& Huesemann, 2011) too narrowly address problems - often less focused on social, political, economic and other contextual factors that may adversely affect engineering designs and uses. In his analyses of genetically-modified (GM) salmon, for instance, Pierce (2013) suggested that engineered fish can be seen, on their own, as large, plentiful and readily-available food sources to solve world hunger. Like a Trojan horse (Bencze \& Carter, 2015), however, positive symbolic (semiotic) messages inherent to the salmon - such as its suggestions of bountiful nourishment and easy-availability - can distract customers from noticing possibly-problematic actants, such as government regulation policies (FDA) that funnel wealth towards companies and increased disease in GM and wild salmon from sea lice that tend to grow in seaside pens. A similar sort of masquerade appears to apply to uses of micro-beads (tiny balls of plastic mixed into numerous hygiene and beauty products) — which many activists want banned (see: goo.gl/vm8trG). In terms of actor-network theory, such subterfuge can work because entities are punctualized (Callon, 1991); that is, made to appear as single (or, at least, highly reduced) entities/actants rather than as part of larger, much more complex — and possibly-problematic — networks.

For the WISE TechDesign project, students were told they could design (as Signs) inventions (phenomena/technologies that did not exist) or innovations (modifications of existing technologies) that they intended to exist in the World — such as a cosmetic that they believe is 'better' than those currently available. Of course, students' definitions of 'better' for whatever technology they would design would vary depending at least on their knowledge (e.g., of cosmetics) and on ideological positions that may influence gaps between their knowledge (Signs) and inventions/innovations (World) they produce (Figure 2). This, in turn, raises crucial questions about the extent to which teachers provide students with resources — or guide them - as they design their products. On the one hand, there has been a long tradition of engaging students in inquiry-based learning (IBL) - a practice that, apparently, continues with many recent STEM education initiatives (Duschl \& Bybee, 2014). Although IBL practices vary in the extent of teacher guidance, many appear to be structured to assume students will learn important 'products' (e.g., laws, theories \& inventions/innovations) of science and technology through different kinds of investigations - some empirically-based, while others involve accessing information in public sources. Schwartz, Lederman and Crawford (2004), for instance, who have written much about IBL, suggest it often can be characterized as follows: "Within a classroom, scientific inquiry involves student-centered projects, with students actively engaged in inquiry processes and meaning construction, with teacher guidance, to achieve meaningful understanding of scientifically accepted ideas targeted by the curriculum" (p. 612). Such 'guided discovery' can be problematic, from several perspectives (Bencze \& Alsop, 2009). Firstly, for example, because of limitations of intelligence, experience, cultural membership, etc., students may not 'discover' intended attitudes, skills and knowledge (ASK) through their observations/readings (Hodson, 1986). Thus, IBL activities can be discriminatory - reproducing existing (systems of) stratification. Secondly, in light of private sector actions to alter information available to the general public through, for example, paying 'reputable' scientists to conduct investigations leading to publications or to simply affix their names to companyproduced publications that cast commercial products like cigarettes, pesticides, pharmaceuticals, etc. in good light (or discredit opposite claims) (Oreskes \& Conway, 2010), students' inquiries may be biased in favour of powerful actants in societies.

Given limitations like those above on many students' abilities to gain access to valid and important ASK through their inquiries, we recommend that teachers use direct instructional methods (Teacher Teaches, Figure 1) to help ensure all students have access to them. The student who produced the video in Figure 2 was taught, for instance, about some main principles of actor-network theory, how to develop actor-network maps, dispositifs and about the Trojan horse concept often is used in consumerism (refer above). To supplement instruction about this latter concept, the teacher also engaged students in discussions about consumerism after they had viewed The Story of Stuff video (storyofstuff.org/movies/story-of-stuff). Once students have ASK like 
this, which represent kinds of Signs in the schema in Figure 2, they can then educate people using such attitudes, skills and knowledge. As well, as noted above, they can develop inventions and/or innovations that draw from such ASK. Indeed, after being taught about ANT, dispositifs and semiotics of consumerism, along with some general ideas about the nature of technology design, students in a tenth-grade class in Ontario were able to develop inventions/innovations (mostly the latter) that not only functioned but considered wellbeing of related individuals, societies and/or environments. For example, after analyses of a common cologne marketed to males, students developed an alternative cologne that they felt was more socially-just and ecologically sound - as perhaps indicated by their comments about the cologne:

The cologne itself is made from primarily pure and natural ingredients these include: Bergamot essential oil, cedar wood essential oil, lemon, cinnamon sticks, green tea leaves, and absolute vodka. Many of our ingredients, if not grown in Canada do not contain harsh chemicals so the people working in other countries to harvest cinnamon for example, would not be exposed to dangerous fumes.... [T] he production process of cork is less harmful to the environment then making a glass or plastic lid, the cork is stripped off the trunk of the tree every 9 or 10 years, this does not kill the tree. ... Our product would appear more attractive to a consumer because they are able to read and identify all seven ingredients and maybe even have majority of them in their household. ... A particularly salient feature of all student groups' networks appeared to be awareness that many commodities were produced by poor people working under inadequate labour conditions in far-away places: [ $\mathrm{f} f$ you have a product and you are producing it in a Third World country, where you are not giving people the proper amount of pay and they are living in a low ['destitute'] place, then that society is not doing well - and that is partly due to your product ... [and] ... [W] strongly believe in fair wages, unlike other manufacturing plants around the world, and will only employ legal and adult workers.... What makes our product more attractive to a consumer than the original antiperspirants is that it hides nothing behind closed doors. ... [I]t is a 'what you see is what you get' type of product ... (Bencze \& Krstovic, 2017, p. 211).

\section{Going Up Against The Borg ${ }^{\text {TM }}$}

The STEPWISE pedagogical framework (lower half, Figure 1) appears to have helped many students to develop creative and relatively-influential research-informed and negotiated action (RiNA) projects — like those highlighted above — to address harms students perceive in relationships among fields of science and technology and societies and environments (STSE). Having said that, a recent case of teachers' promotion of student-led RiNA projects suggests continuing — or, perhaps, increasing — opposition to aspects of such projects. In working with a teacher ('Dylan') who has been highly committed to ideals of the STEPWISE programme, including: student expression of pre-instructional ideas, teacher's teaching of de-punctualized and problematizing conceptions of STSE relationships, student-led research and socio-political actions to address harms perceived by students in STSE relationships, it became apparent that there are barriers to achievement of such goals by such committed teachers (Bencze et al., 2019). Like other teachers we have recently studied in the same school district, 'Dylan' used the RiNA project as a form of inquiry-based learning (IBL). As illustrated by the schema in Figure 3, students are assigned a RiNA project that would start with them choosing an STSE issue as a basis for research, negotiation and actions to address their selected issue. This approach contrasts with the pedagogical approach illustrated in the bottom of Figure 1, in which students are first engaged in 'apprenticeship' activities prior to being asked to self-direct RiNA projects. As well, the apprenticeship in Figure 1 places the Teacher Teaches components of the apprenticeship prior to any RiNA project work, either as part of the apprenticeship (which may involve some teacher support) or as student-led RiNA projects. In Dylan's approach, the aspects — such as "ANT, dispositifs \& World $\leftarrow \rightarrow$ Sign relationships" — of the Teacher Teaches component were inserted at strategic points as students proceeded through their RiNA projects. 


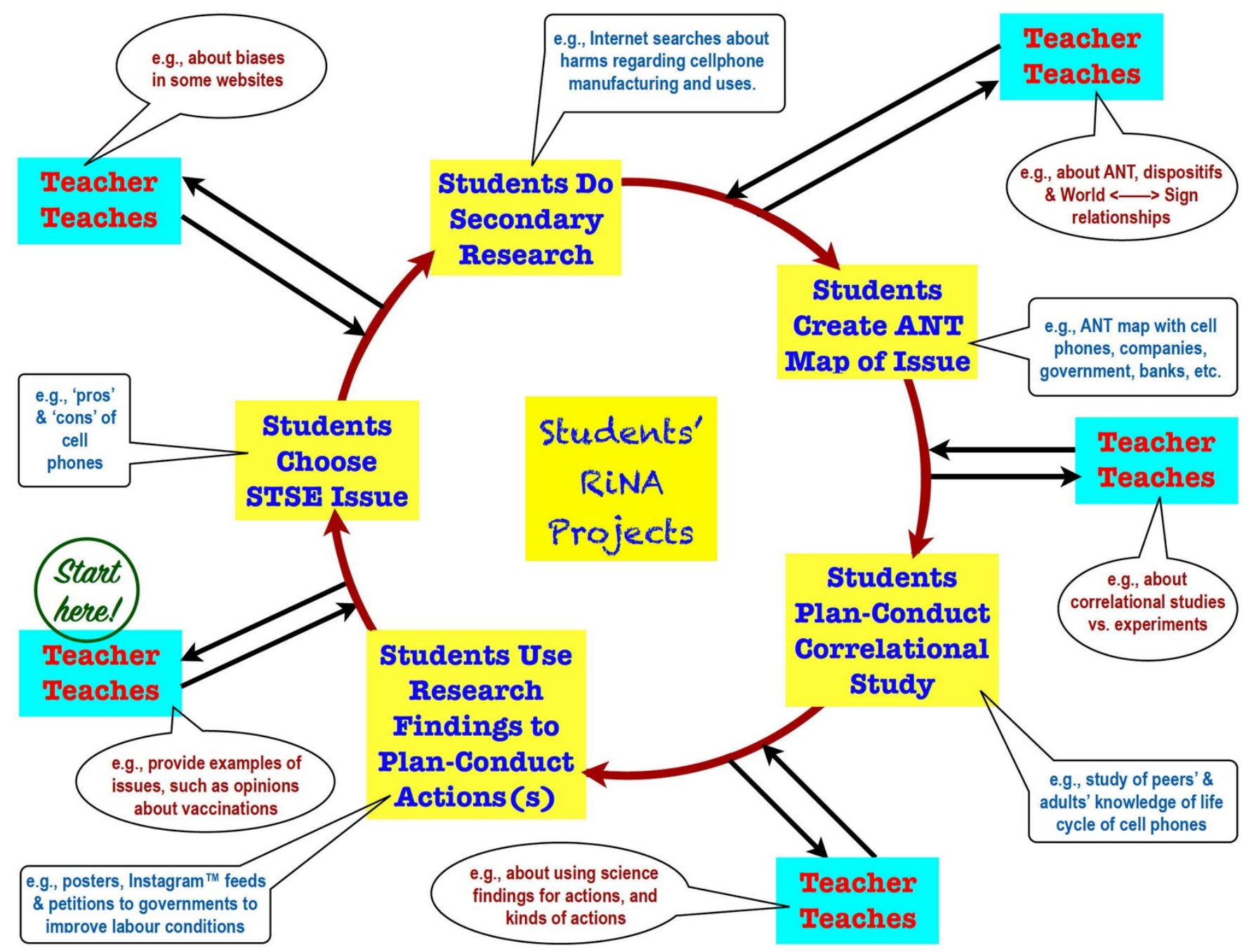

Figure 3: RiNA Projects as IBL.

The approach in Figure 3 seems to represent a compromise to the approach recommended in Figure 1. As argued elsewhere (Bencze \& Alsop, 2009) and above, as a mechanism for powerful people and groups that have - like The Borg ${ }^{\mathrm{TM}}$ — ensnared most entities worldwide in support of capitalist ends, IBL approaches can contribute to social stratification and general disempowerment (in many ways). On the one hand, the approach used by 'Dylan' may, for instance, give students an unrealistically positive conception of progress of science and technology — in that the teacher regularly intervened (Teacher Teaches) during students' research, negotiations and actions and, therefore, could have made RiNA projects seem easier than they are in more independent contexts. Making science and technology processes to appear to inevitably lead to useful conceptions and products and services can be cast positive lights on capitalists, which largely influence fields of science and technology (and many other entities). On the other hand, given that — as he said, and was supported by teachers and school principals - perhaps he had little choice but to incorporate RiNA projects as forms of IBL because there were numerous expectations that IBL was a priority practice for education in their school district. Although adhering to this mandate, however, Dylan had managed to tailor his use of IBL in ways that students were not so disadvantaged by lack of access to difficult-to-discover (either via primary or secondary research) attitudes, skills and knowledge because of his strategic teaching of them throughout their projects. Most students in his class of tenth-grade science developed innovations - such as 3D-printed athletic shoes, a candle recycling device and a biodegradable potato chip bag — that had considerable 
functionality; and, as well, had designs intended to increase social justice and environmental wellbeing (e.g., using locally-sourced and biodegradable materials), making considerable reference to sets of cooperating actants (e.g., involving companies, workers, transportation systems, etc.) (Bencze et al., accepted).

\section{Summary and Ways Forward}

Encouraging and enabling young people, via facilitated action research, to critically evaluate relationships among fields of science and technology and other members of societies and environments — often involving adverse influences of powerful socio-economic actors - and to develop research-informed and negotiated actions to try to rectify harms they perceive in such relationships has, largely, been an uphill battle. Although we have reported numerous successes in this regard over the dozen or so years in which STEPWISE schema have been used as frameworks for promoting such critical and action-oriented civic engagement, implementation of such practices has been largely restricted to relatively-rare contexts in which supportive collections of living, nonliving and symbolic actants (dispositifs) exist. Moreover, as reported here, it seems that even teachers committed to promotion of critical and action-oriented science and technology education must compromise some of their ideals — such as by promoting such education, albeit in perhaps helpful ways, in the context of possibly-problematic inquiry-based learning activities. In a related finding, students in a science class were able to use the dispositif concept to design and develop innovations that not only functioned but also aimed to increase social justice and environment wellbeing. But, at the same time, it was apparent - as concluded by much earlier research — students were much less able to use the dispositif concept to mobilize their ecojust innovations; that is, to engage a network of cooperating living, nonliving and symbolic actants - such as advertisements, politicians, company executives, factory workers, etc. — to form a dispositif supporting global social justice and ecological wellbeing (Bencze et al., accepted).

As argued above, limitations we have seen in promoting STEPWISE-informed perspectives and practices may be explained, at least in part, due to overwhelming influences of pro-capitalist individuals (e.g., financiers) and groups (e.g., banks, corporations, think tanks, transnational trade organizations, universities, governments, etc.) on fields of science and technology, their educational counterparts and most other entities around the globe. Going up against this Borg ${ }^{\mathbf{T M}}$-like collective seems daunting. It seems that individuals in local contexts can make some gains, but may — ultimately — be severely frustrated. Although there are, likely, various approaches enabling some successes in challenging global power structures, Evans (2012) has suggested that mobilization may be possible if ecojustice (and, perhaps, ecosocialist [Löwy, 2015]) actors systematically work to rally many and diverse living, non-living and symbolic (semiotic) actants in ways that an ecojust dispositif emerges/develops. Indeed, a small-scale version of such a counter-hegemonic dispositif seemed to emerge in the case of citizens' efforts to eliminate (what they determined to be) toxic dust (containing many heavy metals, such as lead and cobalt) dispersal from the local port onto their neighbourhood (Bencze \& Pouliot, 2017). Although the local 'development' dispositif (which appears to promote growth of port activities, regardless of possible environmental hazards) seemed quite powerful, reductions in dust dispersal in this context offers some hope for those wanting a more ecojust world.

In eyes of activists, individuals/groups promoting economic growth with less than desirable attention to wellbeing of many individuals, societies and/or environments, may be considered oppressors (Freire, 1970). Educating students about potentially problematic power relations involving fields of science and technology may, therefore, represent a kind of conscientization - a critical consciousness about a social milieu (Freire, 1970). At the same time, educators in democracies may not want to be guilty of oppression, in the sense of providing students with mis-translations of 'real-world' phenomena like those highlighted here — presenting pro-capitalist individuals/groups in an unrealistically bad light. It seems that no educator can avoid ontological gaps and, likely, ideological gaps (see Figure 2). Accordingly, as Freire (1970) recommended, to be free of 
potential oppressors (including teachers), learners need to be given full control over 'praxis'; that is, critical, reflective, practice. Levinson (2010) echoes this call in his discussion of possible citizenship roles in the context of socioscientific issues education. This recommendation is, actually, built into the STEPWISE framework when students are encouraged to engage in student-directed and open-ended (when conclusions are not predetermined; but, rather, determined by learners in the context of experiences and their existing theory, etc.) RiNA projects (see Figures $1 \& 2$ ). Indeed, there appears to be evidence to suggest that students may become relatively free of teacher influence in their RiNA projects, after having been provided with nurturing pedagogical lessons and activities beforehand (Bencze, 2017b; Bencze \& Alsop, 2014).

\section{References}

Agamben, G. (2005). State of exception (trans. K. Attell). Chicago: University of Chicago Press.

Ball, S.J. (2012). Global education inc.: New policy networks and the neo-liberal imaginary. New York: Routledge.

Baudrillard, J. (1998). The consumer society. London: Sage.

Bencze, J.L. (2001). Subverting corporatism in school science. Canadian Journal of Science, Mathematics and Technology Education, 1(3), 349-355.

Bencze, J.L. (ed.) (2017a). Science \& technology education promoting wellbeing for individuals, societies \& environments. Dordrecht: Springer.

Bencze, L. (2017b). Critical and activist science education: Envisaging an ecojust future. In J.L. Bencze (Ed.), Science \& technology education promoting wellbeing for individuals, societies \& environments (pp. 659-678). Dordrecht: Springer.

Bencze, J.L., \& Alsop, S. (2009). A critical and creative inquiry into school science inquiry. In W.-M. Roth \& K. Tobin (Eds.), The world of science education: North America (pp. 27-47). Rotterdam: Sense.

Bencze, J.L., \& Alsop, S. (eds.). (2014). Activist science \& technology education. Dordrecht: Springer.

Bencze, J.L., \& Carter, L. (2015). Capitalists’ profitable virtual worlds: Roles for science \& technology education. In P.P. Trifonas (Ed.), International handbook of semiotics, vol. 1 \& 2 (pp. 1197-1212). Dordrecht: Springer.

Bencze, L., Del Gobbo, D., El Halwany, S., Krstovic, M., Milanovic, M., Mitchell, K., \& Zouda, M. (2019). Socially-conscious youth using STEM (SYSTEM): Towards 'Vision III' science literacy. A presentation at the annual conference of the American Educational Research Association, Toronto, ON, April 5-9, 2019.

Bencze, L., Del Gobbo, D., El Halwany, S., Milanovic, M., Qureshi, N., Padamsi, Z., \& Zouda, M. (accepted). EcoJust engineering assemblages in school science. A presentation at the semi-annual conference of the European Science Education Research Association, Bologna, Italy, Aug. 26-30, 2019.

Bencze, L., \& Krstovic, M. (2017). Science students' ethical technology designs as solutions to socioscientific problems. In J.L. Bencze (Ed.), Science \& technology education promoting wellbeing for individuals, societies \& environments (pp. 201-226). Dordrecht: Springer.

Bencze, L., \& Pouliot, C. (2017). Battle of the bands: Toxic dust, active citizenship and science education. In J.L. Bencze (Ed.), Science \& technology education promoting wellbeing for individuals, societies \& environments (pp. 381-404). Dordrecht: Springer. 
Bencze, L., Reiss, M., Sharma, A., \& Weinstein, M. (2018). STEM education as 'Trojan horse': Deconstructed and reinvented for all. In L. Bryan \& K. Tobin (Eds.), 13 questions: Reframing education's conversation: Science (pp. 69-87). New York: Peter Lang.

Callon, M. (1991). Techno-economic networks and irreversibility. In J. Law (Ed.), A sociology of monsters: Essays on power, technology and domination (pp. 132-161). London: Routledge.

Chomsky, N. (2017). Optimism over despair: On capitalism, empire, and social change. Chicago, IL: Haymarket.

Duschl, R., \& Bybee, R.W. (2014). Planning and carrying out investigations: An entry to learning and to teacher professional development around NGSS science and engineering practices. International Journal of STEM Education, 1(1), 1-9.

Evans, P. (2012). Counter-hegemonic globalization. In G. Ritzer (Ed.), The Wiley-Blackwell encyclopedia of globalization (pp. 1-7). Chichester: Wiley-Blackwell.

Fenwick, T., \& Edwards, R. (eds.) (2012). Researching education through actor-network theory. Chichester, West Sussex, UK; Malden, MA: Wiley-Blackwell.

Fingas, M. (ed.) (2015). Handbook of oil spill science and technology. Hoboken, NJ: John Willy \& Sons.

Foucault, M. (2008). The birth of biopolitics: Lectures at the Collége de France, 1978-1979 (Ed., M. Senellart). New York: Palgrave Macmillan.

Freire, P. (1970). Pedagogy of the oppressed. New York: Continuum.

Giroux, H.A., \& Giroux, S.S. (2006). Challenging neoliberalism's new world order: The promise of critical pedagogy. Cultural Studies $\leftrightarrow$ Critical Methodologies, 6(1), 21-32.

Gough, A. (2015). STEM policy and science education: Scientistic curriculum and sociopolitical silences. Cultural Studies of Science Education, 10(2), 445-458.

Hardt, M., \& Negri, A. (2009). Commonwealth. Cambridge: Belknap Press of Harvard University Press.

Harvey, D. (2005). A brief history of neoliberalism. New York: Oxford University Press.

Hodson, D. (1986). The nature of scientific observation. School Science Review, 68(242), 17-29.

Hodson, D. (2003). Time for action: Science education for an alternative future. International Journal of Science Education, 25(6), 645-670.

Hodson, D. (2011). Looking to the future: Building a curriculum for social activism. Rotterdam: Sense.

Hoeg, D., \& Bencze, L. (2017a). Rising against a gathering storm: A biopolitical analysis of citizenship in STEM policy. Cultural Studies of Science Education, 12(4), 843-861.

Hoeg, D., \& Bencze, L. (2017b). Values underpinning STEM education in the USA: An analysis of the Next Generation Science Standards. Science Education, 101(2), 278-301.

Huesemann, M., \& Huesemann, J. (2011). Techno-fix: Why technology won't save us or the environment. Gabriola, BC: New Society Publishers.

Klein, N. (2007). The shock doctrine: The rise of disaster capitalism. New York: Henry Holt.

Klein, N. (2014). This changes everything: Capitalism vs. the climate. Toronto: Simon \& Schuster.

Kirkpatrick, A. (2017). Understanding in a post-truth world: Comprehension and co-naissance as empathetic antidotes to post-truth politics. Cosmos and History: The Journal of Natural and Social Philosophy, 13(3), 312335. 
Krimsky, S. (2003). Science in the private interest: Has the lure of profits corrupted biomedical research? Lanham, MD: Rowman \& Littlefield.

Laclau, E. (2005). On populist reason. New York, NY: Verso.

Latour, B. (2005). Reassembling the social: An introduction to actor-network-theory. Oxford: Oxford University Press.

Latour, B., \& Woolgar, S. (1986). Laboratory life: The construction of scientific facts (2 ${ }^{\text {nd }}$ ed.). Princeton: Princeton University Press.

Legardez, A., \& Simonneaux, L. (2006). L'école a l'épreuve de l'actualité - Enseigner les questions socialement vives. Paris: ESF.

Leonard, A. (2010). The story of stuff: How our obsession with stuff is trashing the planet, our communities, and our health - and a vision for change. New York: Free Press.

Levinson, R. (2010). Science education and democratic participation: An uneasy congruence? Studies in Science Education, 46(1), 69-119.

Levinson, R. (2013). Practice and theory of socio-scientific issues: An authentic model? Studies in Science Education, 49(10), 99-116.

Levinson, R. (2018). Realizing the school science curriculum. The Curriculum Journal, 29(4), 522-537.

Löwy, M. (2015). Ecosocialism: A radical alternative to capitalist catastrophe. Chicago, IL: Haymarket.

Mayer, J. (2016). Dark money: The hidden history of the billionaires behind the rise of the radical right. New York: Doubleday.

McMurtry, J. (2013). The cancer stage of capitalism: From crisis to cure. London: Pluto.

Mecklin, J. (ed.) (2019). A new abnormal: It is still 2 minutes to midnight, 2019 Doomsday Clock statement. Chicago, IL: Science and Security Board, Bulletin of the Atomic Scientists.

Mirowski, P. (2011). Science-mart: Privatizing American science. Cambridge, MA: Harvard University Press.

Moore, J.W. (2015). Capitalism in the web of life: Ecology and the accumulation of capital. London and New York: Verso.

Moore, J.W. (2016). Anthropocene or capitalocene?: Nature, history, and the crisis of capitalism. Oakland, CA: PM Press.

National Research Council [NRC] (2011). Successful STEM education: Identifying effective approaches in science, technology, engineering, and mathematics. Washington, DC: National Academies Press.

Noffke, S.E., \& Somekh, B. (Ed.) (2009). The SAGE handbook of educational action research. Los Angeles and London: Sage Publications.

Norman, G.A., Jackson, S., Rosenbaum, S.H., \& Palmer, S.K. (eds.) (2011). Clinical ethics in anesthesiology: $A$ case-based textbook. Cambridge, MA: Cambridge University Press.

Oreskes, N., \& Conway, E. (2010). Merchants of doubt. London: Bloomsbury Press.

Oxfam (2017). Reward work, no wealth: To end the inequality crisis, we must build an economy for ordinary working people, not the rich and powerful. Oxford, UK: Oxfam International.

Pedretti, E., \& Nazir, J. (2011). Currents in STSE education: Mapping a complex field, 40 years on. Science Education, 95(4), 601-626.

Pierce, C. (2013). Education in the age of biocapitalism: Optimizing educational life for a flat world. New York: Palgrave Macmillan. 
Piketty, T. (2014). Capital in the twenty-first century. Cambridge, MA: Cambridge University Press.

Pleasant, J., \& Olson, J.K. (2018). What is engineering?: Elaborating the nature of engineering for K-12 education. Science Education, 103(1), 145-166.

Roth, W.-M. (2001). Learning science through technological design. Journal of Research in Science Teaching, $38(7), 768-790$.

Roth, W.-M., \& Désautels, J. (eds.) (2002). Science education as/for sociopolitical action. New York: Peter Lang.

Rushe, D., Milman, O., Redden, M., Lartey, J., Smith, D., \& Oliver Laughland, O. (2017). Six ways Trump is 'dismantling' the US after six months in office. The Guardian, July 19, 2017. Available at: https://www.theguardian.com/us-news/2017/jul/19/six-ways-trump-is-dismantling-america-aftersix-months-in-white-house\#img-2

Santos, W.L.P. dos (2009). Scientific literacy: A Freirean perspective as a radical view of humanistic science education. Science Education, 93(2), 361-382.

Schwartz, R.S., Lederman, N.G., \& Crawford, B.A. (2004). Developing views of nature of science in an authentic context: An explicit approach to bridging the gap between nature of science and scientific inquiry. Science Education, 88(4), 610-645.

Sjöström, J., Frerichs, N., Zin, V.G., \& Eilks, I. (2017). Use of the concept of Bildung in the international science education literature, its potential, and implications for teaching and learning. Studies in Science Education, 53(2), 165-192.

Springer, S., Birch, K., \& MacLeavy, J. (Eds.) (2016). The handbook of neoliberalism. New York: Routledge.

Steffen, W., Rockström, J., Richardson, K., Lenton, T.M., Folke, C., Liverman, D., Summerhayes, C.P., Barnosky, A.D., Cornell, S.E., Crucifix, M., Donges, J.F., Fetzer, I., Lade, S.J., Scheffer, M., Winkelmann, R., \& Schellnhuber, H.J. (2018). Trajectories of the Earth system in the anthropocene. Proceedings of the National Academy of Sciences of the United States of America, 115(33), 8252-8259.

Usher, R. (2010). Consuming learning. In J.A. Sandlin \& P. McLaren (Eds.), Critical pedagogies of consumption: Living and learning in the shadow of the "Shopocalypse" (pp. 36-46). New York: Routledge.

Verma, M. (ed.) (2009). Cancer epidemiology: Modifiable factors. Totowa, NJ: Humana Press.

Weinstein, J.N. (2007). Threats to scientific advancement in clinical practice. SPINE, 32(11S), S58-S62.

Zeidler, D.L. (2014). Socioscientific issues as a curriculum emphasis: Theory, research and practice. In N.G. Lederman \& S.K. Abell (Eds.), Handbook of research on science education, volume II (pp. 697-726). New York, NY: Routledge.

Zeidler, D.L. (2016). STEM education: A deficit framework for the twenty first century? A sociocultural socioscientific response. Cultural Studies of Science Education, 11(1), 11-26. 